\title{
Customers' Satisfaction relative to the Operational Services of the College of Arts and Sciences: Basis for its Continuous Quality
} Improvement

\author{
Maria Luisa A. Valdez, PhD, Dairen P. De Luna, Chin Chin H. Diaz, Jonel M. \\ Corral, Almerian B. Tayobong
}

College of Arts and Sciences, Batangas State University ARASOF-Nasugbu, Philippines

Received: 1 Oct 2020; Received in revised form: 11 Nov 2020; Accepted: 16 Nov 2020; Available online: 21 Nov 2020 (C2020 The Author(s). Published by Infogain Publication. This is an open access article under the CC BY license (https://creativecommons.org/licenses/by/4.0/).

\begin{abstract}
In higher education institutions, quality assurance focuses on the process of verifying whether products or services meet or exceed customer expectations. Thus, this study was conducted to determine the customers' evaluation as regards their satisfaction relative to the operational services of the BatStateU ARASOF-Nasugbu Campus' College of Arts and Sciences within the rating period covering July up to December 2019. Specifically, it tried to determine the respondents' evaluation of the operational services rendered by the College in terms of politeness/courtesy given by staff/service provider; reasonable time of service delivery; knowledge and competence of staff/ service provider; accomplishment of purpose of visit/transaction; no extra fees / charges other than what is required; professional treatment and assistance given; and physical setup and condition of the facilities. Likewise, corrective measures were proposed geared towards its operational services' continuous quality improvement. The study employed the descriptive research method and included a total of four hundred twenty-eight (428) respondents chosen through the convenient sampling method. Findings of the study revealed the Outstanding Service rendered as the overall result of the customer satisfaction survey of the College of Arts and Sciences. However, improvement or changes may still be considered specifically in these two dimensions: the accomplishment of purpose of visit/transaction and the physical setup and condition of the facilities.
\end{abstract}

Keywords-College of Arts and Sciences, Continuous Quality Improvement, Customers' Satisfaction, International Organization for Standardization, Operational Services, Quality Assurance.

\section{INTRODUCTION}

Nowadays, organizations assess their customer satisfaction in order to upsurge the number of their customers, foster their loyalty, increase their profits and market share and consequently increase their survival. Customer satisfaction exemplifies a modern approach for quality in organizations and enterprises and serves the development of a truly customer-focused management and culture [1]. It is considered a vital aspect for service organizations and is highly related to service quality. Such innovation is very much associated with the power of competitions of the current business environment [2]. To a greater extent, organizations underscore service quality owing to its strategic role in upgrading competitiveness specifically in the context of attracting new customers and in enhancing relationship with existing customers [3].

Measuring customer satisfaction proffers a direct, meaningful and objective feedback about clients' preferences and expectations. Through this, the companies' performances may be gauged with regard to a set of satisfaction dimensions that indicate the strengths and weaknesses of business organizations [4]. Thus, service quality dimensions were used as a criterion in the customers' perspective to substantiate if the service sectors 
provided quality services to customers. In doing so, customers were asked if the organizations have quality service as an attribute and if service quality was a selective factor for them to deal with the said organizations.

Service quality in the field of education and higher learning, in particular, is not only essential, but it is correspondingly an important parameter of academic excellence. It has been established that positive perceptions of service quality have a significant influence on student satisfaction and this would eventually entice more students through word-of-mouth communications [5]. The students can be motivated by the academic performances as well as the administrative efficiency of their institution. Ahmed \& Nawaz (2010) [6] pointed out that service quality is a fundamental performance measure in educational excellence and is a foremost strategic variable for universities to create a strong perception in the customers' attention. Most of the well-established higher learning institutions center highly on issues specifically related to providing excellent customer services. It is vital for the reason that by doing so they would be able to make and build good relationships with clients, which is actually very substantial in determining their future in the industry [7].

Moreover, performance measurement of service quality at higher learning institutions is strongly embedded to the matching between customers' expectations and their experience of a particular service [8]. Generally, they evaluate and judge the service quality to be satisfactory by comparing what they want or expect against what they are really getting. Gruber, et al. (2010) [9] believe that the behaviors and attitudes of customer contact employees primarily determine the customers' perceptions of the service quality provided. This means, human interaction element is essential to determine whether students consider the services delivered satisfactory or not. Apart from that, higher learning institutions need to have appropriate infrastructure too such as administrative and academic buildings, residential halls, catering facilities, sports facilities, and recreations centre [10]. Customers, according to Sapri and Finch (2009) [10], are the lifeblood of any organization, whether private or public enterprise sectors.

Customer satisfaction plays an important role in determining accuracy and authenticity of the system being used. The expectation of the customers may go as far as before they even enter and engage in the higher education [11]. Students are likely to be satisfied in their educational institution when the service provided fits their expectations, or they will be very satisfied when the service is beyond their expectations, or completely ISSN: 2456-7620

. satisfied when they receive more than they expect [12]. Same thing holds true with the other customers like the faculty members, employees, parents, alumni and guests. Conversely, they are dissatisfied, according to Petruzzellis, et al., (2006) [12] with the educational institution when the service is less than their expectations, and when the gap between perceived and expected service quality is high, they tend to communicate the negative aspects.

In order to deliver high quality services to its customers, universities must manage every aspect of their customers' interaction with all of their service offerings and in particular those involving its people. In an attempt to deliver total customer satisfaction, all employees of a university should adhere to the principles of quality customer service, whether they be front-line contact staff involved in teaching or administration, or noncontact staff in management or administrative roles [13].

Thus, Rowley (2003) [14] underscores the significance of getting the customers' feedback. He, likewise, identified the following main reasons for collecting customers' feedback: to provide auditable evidence that customers have had the opportunity to pass comment on their transactions and that such information is used to bring about improvements; to encourage customers' reflection on their learning and dealings; to allow institutions to benchmark and to provide indicators that will contribute to the reputation of the university in the marketplace; and to provide customers with an opportunity to express their level of satisfaction with their academic experience.

The rise in the internationalization and globalization of higher education, in particular the rapid development of cross border higher education, has pointed out an urgent need to establish robust frameworks for quality assurance and the recognition of qualification. [15]. The United Nations Educational, Scientific and Cultural Organization's (UNESCO) actions in this area focus on providing information and capacity to empower higher education stakeholders to make better informed decisions in the new world of higher education. This initiative aims to provide information to protect students from inadequate learning resources and low-quality provisions.

Quality assurance is the process of verifying whether products or services meet or exceed customer expectations. It is a process-driven approach with specific steps to help define and attain goals [16]. For UNESCO, quality assurance is the systematic review of educational programs to ensure that acceptable standards of education, scholarship and infrastructure are being maintained. A quality assurance system in the case of a university is said to increase student confidence and the university's 
credibility as a provider of quality services to improve processes and efficiency and to enable a university to better compete with others [17]. Quality assurance, as defined by UNESCO, is an on-going, continuous process of evaluating, which includes assessing, monitoring, guaranteeing, maintaining and improving the quality of higher education systems, institutions or programs. Quality assurance is an all-embracing term covering all the policies, processes, and actions through which the quality of higher education is maintained and developed [18]. In higher education, quality assurance refers to explicit commitment and practices of higher education institutions to the development of an institutional culture which recognizes the importance of quality and the continuous enhancement of quality of services [19].

Moreover, UNESCO underscores that quality assurance can only be effective when all stakeholders understand and embrace its challenges and benefits. Developing a culture of quality requires strong, committed stewardship from global leaders in higher education.

With the rapid expansion in the number of higher education institutions including those of the private sector, ensuring quality has become the major concern of AsiaPacific countries. China, for instance, has a dramatically growing private sector that includes over 500 private higher education institutions, most of which are neither accredited nor formally approved by the government. This is also true for Cambodia, Vietnam and other central Asian nations. During the last decade or so, more than 3,000 selffinancing private academic institutions have emerged in India, out-numbering the public ones in many states. However, the redeeming development is the growing trend and the efforts undertaken to establish National Quality Assurance Agencies. Although the importance of national quality assurance bodies as a more effective mechanism to ensure quality in higher education than the earlier traditional governmental regulatory control is recognized, the process of establishing and using such bodies has yet to be accomplished. Countries like Japan, India, Indonesia, Malaysia, Hong Kong and the Philippines have already established their national quality assurance bodies [20].

The concern for quality in the Philippine Higher Education is enunciated in the Section 1 of Article 14 of the 1987 Philippines Constitution which provides that "the State shall protect and promote the right of all citizens to quality education at all levels." The enactment of Republic Act 7722 [21], otherwise known as the Higher Education Act of 1994 created the Commission on Higher Education (CHED) and directed it to promote and support higher education in the country. It further mandates CHED to monitor and evaluate performance of programs and institutions of higher learning.

To guarantee quality assurance, organizations and enterprises submit themselves to the International Organization for Standardization (ISO). It is an independent, non-governmental international organization with a membership of 163 national standards bodies. International Standards give world-class specifications for products, services and systems, to ensure quality, safety and efficiency. They are instrumental in facilitating international trade. ISO has published 21,671 International Standards and related documents, covering almost every industry, from technology, to agriculture and healthcare and to food safety. ISO International Standards impact everyone, everywhere. Through its members, it brings together experts to share knowledge and develop voluntary, consensus-based, market relevant International Standards that support innovation and provide solutions to global challenges. ISO International Standards ensure that products and services are safe, reliable and of good quality. For business, they are strategic tools that reduce costs by minimizing waste and errors and increasing productivity. They help companies to access new markets, level the playing field for developing countries and facilitate free and fair global trade [22].

In the Philippines, aside from submitting themselves to the Accrediting Agency of Chartered Colleges in the Philippines, Inc.'s standards, government offices and academic institutions have slowly adopted the ISO 9001 standards. This include the Batangas State University (BatStateU), an academic institution that has consistently positioned itself as a premier multi-campus institution of higher education and professional training in Region IV-A. As one of the country's nation builders, this feat is made possible because of the university's commitment to the holistic development of its students providing them a conducive learning environment to generate, disseminate, and utilize knowledge through innovative education, multidisciplinary research collaborations, and community partnerships.

The university's pledge of educational excellence is cascaded to all its eleven (11) campuses with Batangas State University ARASOF-Nasugbu as one of them. Formerly a fisheries school, the integration of the campus to the Batangas State University System proved to be in favor of its growth and development as an educational institution serving the people of Nasugbu, Lian, Calatagan, Tuy, Balayan, Batangas, and other nearby areas. The College of Arts and Sciences (CAS) is one of the flagship colleges of BatStateU ARASOF-Nasugbu offering degree 
programs in Criminology, Psychology, Communication Arts, as well as Fisheries and Aquatic Sciences.

Anchored on its University mission statement, this paper was conducted to serve as the researchers' modest contribution in the attainment of one of the academic institution's goal that is to be an ISO Certified University. Customer satisfaction is important in the ISO 9001 process-based quality standard. The standard recognizes that although processes underpin a healthy organization, meeting customer requirements is fundamental to its success [23]. It is noteworthy to mention that as one of the measurements of the performance of the Quality Management System, the University deemed it necessary to monitor information of customers' perception as to whether the academic institution has met its customers' requirements. Customers' feedback or satisfaction is the initial tool required by the standard to gauge the health of the University's Quality Management System. Thus, this requires the Office of the College of Arts and Sciences to gather and analyze information as to what extent it met their requirements based on its customers' perspective. This paper will be of great help to the University and to the Office of the College of Arts and Sciences in particular because it would provide manifestations that would justify that customers are knowledgeable and satisfied with its operational services.

With these thoughts in mind, the researchers deemed it necessary to conduct this study about the customers' satisfaction relative to the operational services of the Office of the College of Arts and Sciences in order to be used as basis for proposed corrective measures geared towards its continuous quality improvement.

\section{STATEMENT OF THE PROBLEM}

The study aimed to determine the customers' evaluation as regards their satisfaction relative to the operational services of the BatStateU ARASOF-Nasugbu Campus' Office of the College of Arts and Sciences in order to be used as basis for proposed corrective measures geared towards its continuous quality improvement.

Specifically, it aims to answer the following questions:

1. What is the respondents' evaluation of the operational services rendered by the Office of the College of Arts and Sciences in terms of:

1.1 politeness/courtesy given by staff/service provider;

1.2 reasonable time of service delivery;

1.3 knowledge and competence of staff/ service provider;
1.4 accomplishment of purpose of visit/transaction; 1.5 no extra fees / charges other than what is required; 1.6 professional treatment and assistance given; and 1.7 physical setup and condition of the facilities?

2. Based on the result of the study, what corrective measures geared towards continual quality improvement may be proposed?

\section{RESEARCH METHODOLOGY}

3.1 Research Design. The present study employed the descriptive research method. This method is used to obtain information concerning the current status of the phenomena to describe "what exists" with respect to variables or conditions in a situation [24]. This method applies prominently because the present study aimed to determine the customers' evaluation of their satisfaction as regards the operational services of the BatStateU ARASOF-Nasugbu Campus' College of Arts and Sciences in order to come up with proposed corrective measures geared towards its continuous quality improvement.

3.2 Participants of the Study. The respondents of the study include four hundred twenty-eight (428) students who visited the Office of the College of Arts and Sciences particularly the Office of the Associate Dean within the rating period covering July up to December 2019. They were chosen through the convenient sampling method.

3.3 Data Gathering Instruments. In order to attain the objectives of this study, the researcher used documentary materials from reputable publications and electronic sources as well as the BatStateU-FO-CFS-01 or the Customer Satisfaction Survey Form as a basic tool for gathering data. Mercado (1999) [25] defined the questionnaire or survey form as a self-administered research tool which consist of questions and prompts information from the respondents.

3.4 Data Gathering Procedures. An approval to conduct the study was sought from the respondents. After which, the BatStateU-FO-CFS-01 or the Customer Satisfaction Survey Forms were administered to them. They were asked to fill out the said survey forms in order to let the University know their experience as regards the services provided by the Office. After collecting the aforementioned forms, the data were tabulated, analyzed and interpreted by the BatStateU ARASOF-Nasugbu International Organization for Standardization (ISO) Office. The result will help determine if action was taken to resolve an existing problem; if improvements or changes have been made and are now part of the product or services; and if improvement or changes are planned for incorporation into the product or service. Their feedbacks 
will help the College to assist them better and will also serve as input on the improvement of the Office's processes and services. Through their feedbacks, the service providers may start gaining a deeper understanding of their customers and find innovative ways to create a better customer experience.

3.5 Statistical Treatment of Data. The study utilized a frequency distribution. A frequency distribution is a display of data that specifies the number of observations that exist for each data point or grouping of data points. It is a particularly useful method of expressing the relative frequency of survey responses and other data [26]. It also used the Likert Summated Scale Rating, which is a psychometric response scale primarily used in questionnaires to obtain participant's preferences or degree of agreement with a statement or set of statements. Likert scales are a non-comparative scaling technique and are unidimensional (only measure a single trait) in nature. Respondents are asked to indicate their level of agreement with a given statement by way of an ordinal scale [27]. With reference to this, the customers were asked to fill out the BatStateU-FO-CFS-01 or the Customer Satisfaction Survey Form. They were asked to supply the needed information and mark the column that corresponds to their answers with 5 (for Outstanding Service); 4 (for Very Satisfactory Service); 3 (for Satisfactory Service); 2 for (Unsatisfactory Service; and 1 (for Poor Service) rendered.

3.6 Data Analysis. As with all data, analysis and interpretation are required to bring order and understanding of the study. This requires creativity, discipline and a systematic approach. Thus, the steps relative to analyzing data from the questionnaires and interview schedules, as described by Taylor-Power and Renner (2003) [28], were followed in this study. This include: getting to know the data, focusing the analysis, categorizing information, identifying patterns and connections within and between categories, and interpretation of the data.

Quantitative data analysis in this study primarily employed frequency counts and the mean scores. The mean scores, or average, which is sometimes called the arithmetic mean, is calculated by adding up the scores and dividing the total by the number of scores. Interpretations of means were based on the following scales:

\begin{tabular}{|c|c|c|}
\hline NO. & RANGE & $\begin{array}{c}\text { VERBAL } \\
\text { INTERPRETATION }\end{array}$ \\
\hline 1 & $1.00-1.49$ & Poor Service \\
\hline 2 & $1.50-2.49$ & Unsatisfactory Service \\
\hline 3 & $2.50-3.49$ & Satisfactory Service \\
\hline 4 & $3.50-4.49$ & Very Satisfactory Service \\
\hline 5 & $4.50-5.00$ & Outstanding Service \\
\hline
\end{tabular}

\section{RESULTS AND DISCUSSION}

This study yielded the following results:

4.1 The Respondents' Evaluation of their Satisfaction Relative to the Operational Services of the Office of the College of Arts and Sciences.

The respondents of the study, which include students who availed of the services of the Batangas State University ARASOF-Nasugbu Campus' Office of the College of Arts and Sciences within the rating period, from July to December 2019 were asked to fill out the BatStateU-FO-CFS-01 or the Customer Satisfaction Survey Form. This aimed to let the University know their experiences on the services provided by the Office. Their feedbacks will help the College to assist them better and it will also serve as input on the improvement of the office's processes and services. Through this study, the service providers may start gaining a deeper understanding of their customers and find innovative ways to create a better customer experience.

Table 1 Customers' Experience Relative to the Operational Services of the Office

\begin{tabular}{|c|c|c|c|c|c|c|c|c|}
\hline \multirow{2}{*}{$\begin{array}{c}\text { Customers' Experience Relative } \\
\text { to the Operational Services } \\
\text { of the Office }\end{array}$} & \multicolumn{6}{|c|}{ Mean Scores } & \multirow[t]{2}{*}{ Total } & \multirow[t]{2}{*}{$\begin{array}{c}\text { Verbal } \\
\text { Interpretation }\end{array}$} \\
\hline & Jul. & Aug. & Sept & Oct. & Nov. & Dec. & & \\
\hline $\begin{array}{l}\text { 1. Politeness/courtesy given by } \\
\text { staff/ service provider }\end{array}$ & 4.38 & 4.66 & 4.52 & 4.52 & 4.72 & 4.71 & 4.59 & $\begin{array}{l}\text { Outstanding } \\
\text { Service }\end{array}$ \\
\hline 2. Reasonable time of service & 4.00 & 4.41 & 4.43 & 4.40 & 4.43 & 4.51 & 4.36 & Very \\
\hline
\end{tabular}




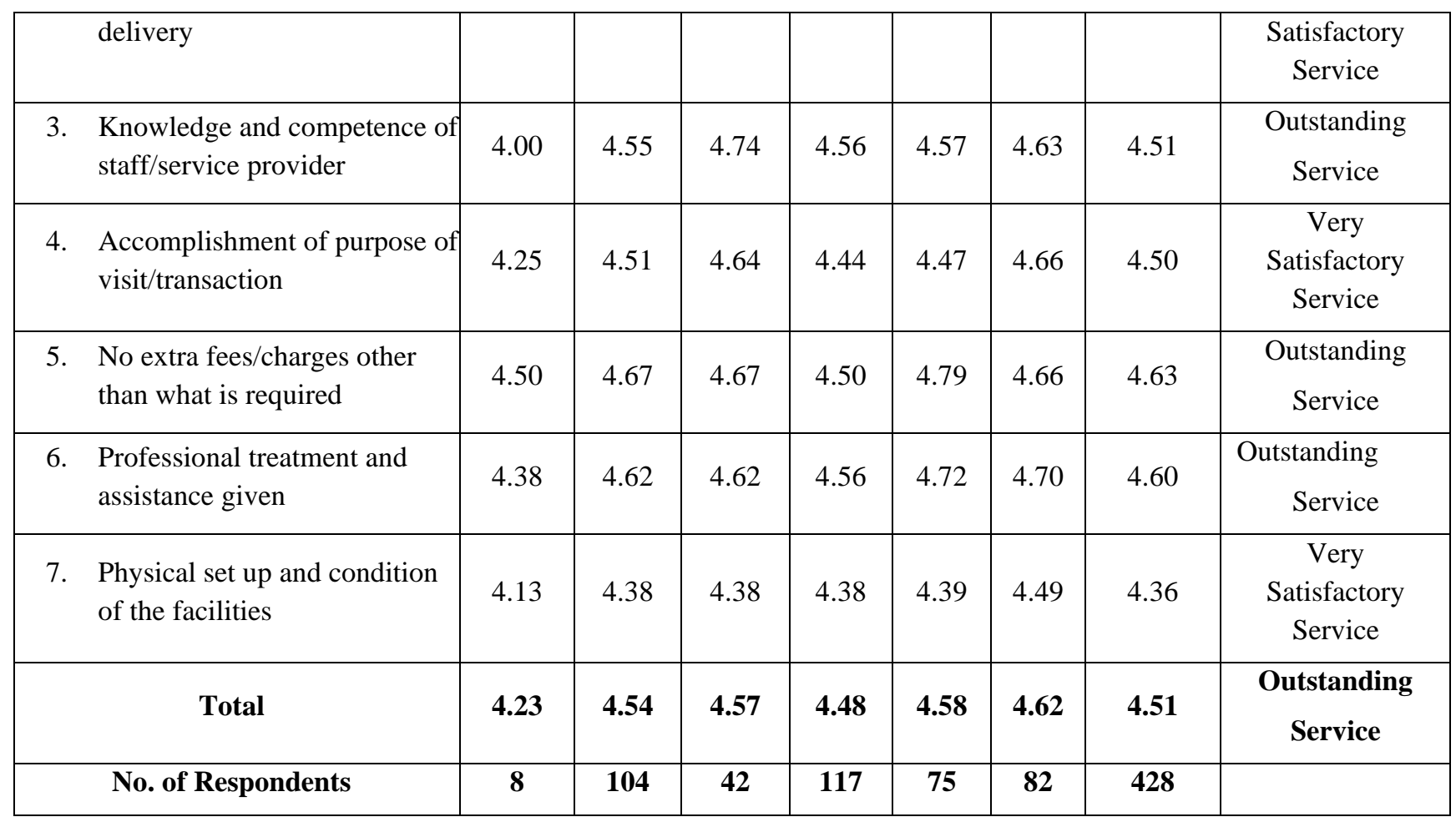

4.1.1 With reference to Politeness/Courtesy Given by Staff/Service Provider, the findings revealed that the service providers have demonstrated politeness, respect, friendliness, and consideration as regards their transaction with their customers during the term. It is noteworthy to mention that this dimension got a mean of 4.59 verbally interpreted as Outstanding Service. This means that the service providers have exhibited the personality traits that customer service people should embody. This finding could be attributed to the respondents' perception that the service providers knew that these attitudes and behaviors are not just nice, but they are indeed expected of them. As simple as it may sound, politeness or courtesy is a tangible asset that can positively impact customer satisfaction with service recovery. Simply put, when the service providers are polite and courteous, customers will experience more satisfaction and reward them with stronger loyalty. This finding supports Liao's (2007) [29] study, which states that when it comes to complaint handling specifically, people know that employee politeness while addressing the issue helps diffuse the problem in the customer's mind. The study also found out that when customers feel like they are being treated with respect, dignity, and sensitivity by employees, they feel a sense of justice and fairness from the institution.

4.1.2 Relative to Reasonable Time of Service Delivery, the findings showed that the service providers have rendered timely and willing service. It is significant to note that this dimension got a mean of 4.36 verbally interpreted as Very Satisfactory Service. This finding could be ascribed to the respondents' belief that the service providers are responsive or capable of producing the desired results without wasting materials, time and energy. Indeed, there are many strategies to help an office deliver efficient customer service, and one of the most powerful ones is its willingness to provide prompt response. This dimension was viewed as the "service time' of the College, which shows when the customers expects the services to be completed. Thus, they ensure that clear service level agreements are set up along with time-based intensifications. This finding conforms to the study of Smith, et al. (1999) [30], which states that the longer it takes for the service provider to provide a full recovery, the greater the customer's perception is that they have been treated unfairly. Thus, Smith, et al.'s study averred that there is a need to improve the organization's ability to handle concerns quickly and well as it will undoubtedly increase customer satisfaction and loyalty.

4.1.3 As regards the Knowledge and Competence of Staff/Service Provider, the findings pointed out that the service providers have the required workplace competency, which include the knowledge and skills about their work or how to do their jobs properly. It is worth mentioning that this dimension got a mean of 4.51 verbally interpreted as Outstanding Service. This finding could be attributed to the respondents' perception that the service providers have the competency, which include 
systems thinking, emotional intelligence, and skills about their jobs. This dimension was viewed as "qualified staff" of the College, which shows that the person rendering the services to customers have the attribute of knowledge and ability to inspire trust and confidence. The service providers' workplace competencies give them a clear guide for what is expected of them in terms of their performance. This supports Dillon's (2017) [31] concept, which states that competencies indicate which behaviors are valued, recognized and rewarded. The focus moves away from formal qualifications and career history of the staff and toward proven capability to do the job as demonstrated through recorded workplace experience. Moreover, for him, each competency consists of knowledge, skill, ability or personal characteristics, sometimes in combination.

4.1.4 In connection with the Accomplishment of Purpose of Visit/Transaction, the findings indicated that the service providers were able to accomplish the purpose of their visit. It is significant to note that this dimension got a mean of 4.50 verbally interpreted as Outstanding Service. This finding could be ascribed to the respondents' insight that the service providers have demonstrated the values of reliability. As used within the context of this study, the term reliability refers to the ability of the service providers to perform the promised service dependably and accurately. This dimension was viewed as "accurate service" of the College, which shows that the customer views the services provided reliable or with very minimal errors. Reliability was also viewed as less queue at the Office's waiting area. However, there may be some instances that the services were not accomplished at once since the Associate Dean or the concerned faculty members or staff whom the visitors have transactions with, were out on official business or not available during the visit.

4.1.5 Concerning No Extra Fees / Charges other than what is Required, the findings manifested that the respondents are aware that the Office does not charge any fee or charges for any of its rendered services. It is essential to note that this dimension got a mean of 4.63 verbally interpreted as Outstanding Service. This finding could be attributed to the fact that the Office believe that collection of money from students other than what is required for any school activity, project or program is illegal and unethical.

4.1.6 Regarding Professional Treatment and Assistance Given, the findings of showed that the service providers treated them professionally and strived to give assistance and made their time with each of them a great experience. It is substantial to note that this dimension got a mean of 4.60 verbally interpreted as Outstanding Service. This finding could be attributed to the respondents' perception that the service providers adhered to the notion that giving professional treatment builds great experiences and customers tell each other about that. Word of mouth is very powerful tool. According to LeBoeuf (as cited by Kerr 2017) [32], a satisfied customer is the best business strategy of all. This conforms to Penney's (2017) [33] concept which says that a courteous treatment will make a customer a walking advertisement. Bruckner (2017) [34] averred that men must go beyond merely communicating to 'connecting' with people. The service providers' knack to communicate is an essential tool in the Office's pursuit of its goals, whether it is with the faculty members, students, co-workers, parents, alumni, clients and customers. Thus, people should never underestimate the power of the human element. The people aspect plays a key role in guest satisfaction and loyalty whether the Office is assisting a guest with a special request or a friendly greeting from staff members in the hallway.

4.1.7 Pertaining to the Physical Setup and Condition of the Facilities, the findings pointed out that the service providers had put a tidy workspace despite the size of its area high on its priority list. The workplace or physical set-up and condition of the room are wellorganized. It is essential to note that this dimension got the lowest mean of 4.36 verbally interpreted as Very Satisfactory Service. This finding could be ascribed to the respondents' belief that even though the space is too small and too crowded to accommodate three visitors at one time, still they believe that the Office is well-organized. It is evident that the service providers find it hard to conveniently move around the office to get the needed records or documents. They are affected by the limited workspace. When talking about organizing the workspace, it is evident that the service providers considered five areas prior to organizing the office. These include: the paper, general stuff such as office supplies, the space and furniture layout, electronic information, and time management. Moreover, designing a comfortable office environment is about more than aesthetics; careful attention to design can give a boost to the service providers' productive office environment.

\subsection{The Office of the College of Arts and Sciences Proposed Corrective Measures Geared towards its Continuous Quality Improvement}

Cognizant of the fact that the University, specifically the BatStateU ARASOF-Nasugbu, College of Arts and Sciences continuously endeavors to maintain its ISO Certification, it is but fitting to monitor information relative to customers' satisfaction as to whether the 
College has met its customers' expectations. Their feedback may provide manifestations that would justify that customers are knowledgeable and satisfied with its operational services.

The College aims to continuously provide efficient and effective support and customer services while fostering a nurturing environment in the delivery of customer services and strengthening collaboration with its internal and external linkages in continuously improving its customer services. Likewise, it standardizes and implements a feedback mechanism that measures satisfaction of its customers. Customer satisfaction is essential in the ISO 9001:2015 risk-based quality standard.

The result of the study prompted the College to propose corrective measures for its continual quality improvement. Priorities, programs, projects and activities of the College of Arts and Sciences' Services are geared towards providing holistic BatStateU Spartan formation programs that integrates its core values of faith, patriotism, human dignity, integrity, mutual respect and excellence to its customer service, which underscores politeness or courtesy as rendered by the staff or service providers, reasonable time of service delivery, knowledge and competition of the staff or service provider, accomplishment of purpose of visit/transaction, no extra fees/charges other than what is required, professional treatment and assistance given and the physical set up and condition of the facilities.

Based on the overall result of the customer satisfaction survey (Mean of 4.51 - Outstanding Service), improvement or changes may still be considered specifically in two dimensions. These dimensions refer to the reasonable time of service delivery (Mean of 4.36; Very Satisfactory Service) and the physical set up and condition of the facilities (Mean of 4.36; Very Satisfactory Service). It is significant to note that even though the said dimensions both received a verbal interpretation of Very Satisfactory Service, the service providers may still improve its services in relation to the said areas by ensuring that communication will be available even though the concerned faculty members are not available in the Office during the customers' visit. On the part of the Associate Dean, faculty members and staff, they will be informed that their timely and willing service as well as their availability in times of client's visit/transaction is vital as it is part of their responsibility as service providers. As for the clients, they will be assured of a feedback in person, through Gmail, or via mobile communication when their concerns will be accomplished or completed within a considerable period of time. With reference to the physical set up and condition of the facilities, the service providers may consider maintaining a well-organize workplace until such a time that a bigger work space is available for the office and ensuring that available facilities are in good working condition. Moreover, clients will be warranted that an integrated approach to operating, maintaining, improving, and adapting of facilities will be continuously adhered to by the College towards achieving optimum customer satisfaction.

\section{CONCLUSIONS}

Based on the foregoing findings, the following conclusions are drawn:

5.1 In relation to the customers' evaluation of their satisfaction as regards the operational services offered by the BatStateU ARASOF Nasugbu College of Arts and Sciences, findings of the study pointed out that:

5.1.1 With reference to Politeness/Courtesy Given by Staff/Service Provider, the findings revealed that the service providers have demonstrated politeness, respect, friendliness, and consideration as regards their transaction with their customers during the term. It is noteworthy to mention that this dimension got a mean of 4.59 verbally interpreted as Outstanding Service.

5.1.2 Relative to Reasonable Time of Service Delivery, the findings showed that the service providers have rendered timely and willing service. It is significant to note that this dimension got a mean of 4.36 verbally interpreted as Very Satisfactory Service.

5.1.3 As regards the Knowledge and Competence of Staff/Service Provider, the findings pointed out that the service providers have the required workplace competency, which include the knowledge and skills about their work or how to do their jobs properly. It is worth mentioning that this dimension got a mean of 4.51 verbally interpreted as Outstanding Service.

5.1.4 In connection with the Accomplishment of Purpose of Visit/Transaction, the findings indicated that the service providers were able to accomplish the purpose of their visit. It is significant to note that this dimension got a mean of 4.50 verbally interpreted as Outstanding Service.

5.1.5 Concerning No Extra Fees / Charges other than what is Required, the findings manifested that the respondents are aware that the Office does not charge any fee or charges for any of its rendered 
services. It is essential to note that this dimension got a mean of 4.63 verbally interpreted as Outstanding Service.

5.1.6 Regarding Professional Treatment and Assistance Given, the findings of showed that the service providers treated them professionally and strived to give assistance and made their time with each of them a great experience. It is substantial to note that this dimension got a mean of 4.60 verbally interpreted as Outstanding Service.

5.1.7 Pertaining to the Physical Setup and Condition of the Facilities, the findings pointed out that the service providers had put a tidy workspace despite the size of its area high on its priority list. The workplace or physical set-up and condition of the room are well-organized. It is essential to note that this dimension got the lowest mean of 4.36 verbally interpreted as Very Satisfactory Service.

5.2 With reference to the overall result of the customer satisfaction survey (Mean of 4.51 - Outstanding Service), improvement or changes may still be considered specifically in these two dimensions: the accomplishment of purpose of visit/transaction and the physical setup and condition of the facilities.

\section{RECOMMENDATIONS}

From the findings of the study and conclusions, the following recommendations are hereby endorsed:

6.1 That the College of Arts and Sciences may consider addressing the weak dimensions specified by the customer-respondents.

6.2 That concerned offices in the Campus be identified to address such areas that need improvement.

6.3 That continuing evaluation be conducted by the College in order to have a holistic view of its operational services so that better improvement strategies can be formulated.

\section{REFERENCES}

[1] Mihelis, G., E. Grigoroudis, Y. Siskos, Y. Politis and Y. Malandrakis. (2017). "Customer Satisfaction Measurement in the Private Bank Sector." Retrieved from: http://www.unipi.gr/faculty/ysiskos/files/paper6.pdf.

[2] Lee, M. C. \& Hwan, I. S. (2005). "Relationships among Service Quality, Customer Satisfaction and Profitability in the Taiwanese Banking Industry," International Journal of Management, 22 (4). 635-648.

[3] Ugboma, C., Ogwude, I. C., Ugboma, O. \& Nadi, K. (2007). "Service Quality and Satisfaction Measurements in Nigerian Ports: An Exploration," Maritime Policy \& Management 34 (4). 331-346.
[4] Mihelis, G., E. Grigoroudis, Y. Siskos, Y. Politis and Y. Malandrakis. (2017). "Customer Satisfaction Measurement in the Private Bank Sector." Retrieved from: http://www.unipi.gr/faculty/ysiskos/files/paper6.pdf.

[5] Alves, H. \& Raposo M. (2010). "The Influence of University Image on Students' Behavior," International Journal of Educational Management. 24 (1): 73-85.

[6] Ahmed, I., Nawaz, M. M., Ahmad, Z., Ahmad, Z., Shaukat, M. Z., Usman, A., Wasim-ulRehman \& Ahmed, N. (2010). "Does Service Quality Affect Students' Performance? Evidence from Institutes of Higher Learning,"'African Journal of Business Management, 4 (12). 2527-2533.

[7] Malik, M. E., Danish, R., \& Usman, A. (2010). "Impact of Job Climate and Extrinsic Rewards on Job Satisfaction of Banking Executives: A Case of Pakistan.” Interdisciplinary Journal of Contemporary Research in Business, 1(12), 125139.

[8] Tahar, E. B. M. (2008). "Expectation and Perception of Postgraduate Students for Service Quality in UTM," UTM Thesis, Unpublished.

[9] Gruber, T., Fuß, S., Voss, R. \& Glaser-Zikuda, M. (2010). "Examining Student Satisfaction with Higher Education Services Using a New Measurement Tool," International Journal of Public Sector Management, 23 (2). 105-123.

[10] Sapri, M., Kaka, A. \& Finch, E. (2009). "Factors that Influence Student's Level of Satisfaction with Regards to Higher Educational Facilities Services," Malaysian Journal of Real Estate, 4 (1). 34:51.

[11] Palacio, A. B., Meneses, G. D. and Pérez, P. D. P. (2002). "The Configuration of the University Image and Its Relationship with the Satisfaction of Students", Journal of Educational Administration, Vol. 40 No. 5, pp. 486-505.

[12] Petruzzellis, L., D’Uggento, A. M. \& Romanazzi, S. (2006). "Student Satisfaction and Quality of Service in Italian Universities, Managing Service Quality," 16 (4). 349-364.

[13] Gold, E. (2001). "Customer Service: A Key Unifying Force for Today's Campus." Netresults, National Association of Student Personnel Administration. http://www.naspa.org/netresults (Accessed 8 January 2010).

[14] Rowley, J. (2003). Designing Student Feedback Questionnaires. Quality Assurance in Education, 11(3), 142-149.

[15] The United Nations Educational, Scientific and Cultural Organization (UNESCO). (2002). First Global Forum on International Quality Assurance, Accreditation and the Recognition of Qualifications in Higher Education. UNESCO Paris. Retrieved from: http://unesdoc.unesco.org/images/0013/001314/131402e.pd f.

[16] Ruiz. Adela Jamorabo \& Cecilia Junio-Sabio. (2012). "Quality Assurance in Higher Education in the Philippines." Asian Journal of Distance Education. Retrieved from: http://www.asianjde.org/2012v10.2.Ruiz.pdf. 
[17] Pavlenko, S., Bojan, C., \& Trif, E. (2008). Quality Assurance within the Bologna Process Framework - The Babeş-Bolyai University. In G. Ivan (Ed.), Partners for Quality in Higher Education - Enhancing the Employability of Graduates. British Council.

[18] Campbell, C., \& Rozsnyai, C. (2002). "Quality Assurance and the Development of Course Programmes." Papers on Higher Education Regional University Network. Bucharest: UNESCO.

[19] Defensor, N. (2010). "Quality Assurance in Southeast Asia: The Philippine Experience." SEAMEO RIHED Back to Back Conference on Quality Assurance in Southeast Asian Countries, Bangkok, Thailand.

[20] Gnanam, Arumugam. (2002). International Education and Quality Assurance: A Regional Perspective from the AsiaPacific Region: Quality Assurance in the Asia-Pacific Context. Retrieved from: http://unesdoc.unesco.org/images/0013/001314/131402e.pd f.

[21] Republic Act 7722, Otherwise known as the Higher Education Act of 1994 or the creation of the Commission on Higher Education (CHED).

[22] ISO.org Website. (2017). International Organization for Standardization. Retrieved from: https://www.iso.org/about-us.html.

[23] The 9000store.com Website. (2016). ISO 9001 8.2.1 Customer Satisfaction. Retrieved from: http://the9000store.com/iso-9000-tips-customersatisfaction/.

[24] Key, James P. (1997). Research Design in Occupational Education. Oklahoma State University.

[25] Mercado, Cesar M. (1999). Conducting and Managing Communication Survey Research: The Asian Experience. Quezon City, Philippines: Development Consultants for Asia Africa Pacific (DCAAP).

[26] Methods.sagepub.com Website. (2016). Frequency Distribution. Retrieved from: http://methods.sagepub.com/reference/encyc-of-researchdesign/n159.xml.

[27] Bertram, Dane. (2017). Likert Scales. Retrieved from: http://my.ilstu.edu/ eostewa/497/Likert\%20topic-danelikert.pdf. Accessed on May 01, 2017).

[28] Taylor-Power, Ellen and Marcus Renner. (2003). Analyzing Qualitative Data, url: http://learningstore.uwex.edu/assets/pdfs/g3658-12.pdf, date retrieved: $3 / 17 / 2014$

[29] Liao, Hui. (2007). Do It Right This Time: The Role of Employee Service Recovery Performance in CustomerPerceived Justice and Customer Loyalty After Service Failures. Journal of Applied Psychology. Retrieved from: https://www.researchgate.net/publication/6436631_Do_It_ Right_This_Time_The_Role_of_Employee_Service_Recov ery_Performance_in_Customer-

Perceived_Justice_and_Customer_Loyalty_After_Service_ Failures.

[30] Smith, A.K., Bolton, R.N., Wagner, J. (1999). A Model of Customer Satisfaction with Service Encounters Involving
Failure and Recovery. Journal of Marketing Research, 36(3), 356-372.

[31] Dillon, Shelagh. (2017). What Are Workplace Competencies? http://smallbusiness.chron.com/workplacecompetencies-46820.html.

[32] Kerr, Michael. (2017). Business Strategies of Companies Retrieved from: http://smallbusiness.chron.com/businessstrategies-companies-2622.html.

[33] Penney, James Cash. (2017). Courteous Treatment. Retrieved from: http://www.goodreads.com/quotes/646482courteous-treatment-will-make-a-customer-a-walkingadvertisement.

[34] Bruckner, Jerry. (2017) as cited by Yosuke Carter. Customer Experience. Retrieved from: https://www.partycentersoftware.com/blog/10 inspirational-quotes-about-the-customer-experience. 